\title{
PERBANDINGAN METODE NAÏVE BAYES DAN NETWORK BAYESIAN UNTUK DIAGNOSIS PENYAKIT SKIZOFRENIA BERBASIS WEB
}

\author{
Moch Nurul Furqon, Ahmad Faisol, Febrianan Santi Wahyuni \\ Program Studi Teknik Informatika S1, Fakultas Teknologi Industri \\ Institut Teknologi Nasional Malang, Jalan Raya Karanglo km 2 Malang, Indonesia \\ afurqon832@gmail.com
}

\begin{abstract}
ABSTRAK
Hayunanto Medical Center merupakan klinik yang memberikan pelayanan medis kepada masyarakat umum. Sistem pelayananyang ada di Hayunanto Medical Center masih dilakukan secara manual dalam pencatatan pasien yang ingin konsultasi.Sehingga masih memiliki berbagai kekurangan dan kendala yang dihadapi. Kendala yang dihadapi yaitu sulitnya mendata banyak pasien yang konsultasisetiap hari, proses pendataan yang banyak mengakibatkan pegawai harus kerja extra ketika pasien yang ingin konsultasi banyak, peramalan diagnosis yang kurang akuratkarena dikerjakan secara manualbelum adanya sistem pendukung untuk mempermudah mendiagnosis suatu pasien. Kondisi Pasien yang tidak menentu seiring berubah-ubahnya gejala pasien, mengakibatkan kesulitan untuk menentukan penyakit pasien.

Prediksi adalah suatu proses memperkirakan tentang sesuatu yang mungkin terjadi di masa depan berdasarkan informasi dari masa lalu, agar kesalahannya dapat diperkecil. Prediksi tidak harus memberikan jawaban secara pasti atau benar untuk kejadian yang akan terjadi, melainkan berusaha untuk mencari jawaban semirip mungkin yang akan terjadi. Naive Bayes adalah sebuah metode untuk melakukan prediksi terhadap pasien berdasarkan data pasien yang ada sebelumnya.

Berdasarkan implmentasi dan pengujian yang dilakukan dapat ditarik kesimpulan sebagai berikut. Hasil pengujian fungsional halaman website yang dilakukan pada 3 browser, yaitu MozillaFirefox, InternetExplorer dan GoogleChrome halaman website berhasil berjalan dengan baik sehingga dapat dinyatakan bahwa website bisa berjalan baik di ke-3 web browser .Hasil pengujian keakuratan metode menggunkan 25 data traning dan 5 data testing diperoleh hasil nilai akurasi $100 \%$ dan nilai error sebesar $0 \%$
\end{abstract}

Kata kunci : Naive Bayes, Diagnosis, Gejala, Pasien, Skizofrenia

\section{PENDAHULUAN}

\subsection{Latar Belakang}

Sistem pakar adalah sistem yang berusaha mengadopsi pengetahuan manusia ke komputer yang dirancang untuk menyelesaikan masalah seperti layaknya seorang pakar. Pada saat pengguna menjalankan komputer untuk mendapatkan informasi, sistem pakar menanyakan fakta-fakta dan dapat membuat penalaran (inferensi) dan sampai pada suatu kesimpulan. Kemudian, sistem pakar memberikan penjelasan (memberikan kesimpulan atas hasil konsultasi yang telah dilakukan sebelumnya) .

Hayunanto Medical Center merupakan klinik yang memberikan pelayanan medis kepada masyarakat umum. Sistem pelayanan yang ada di Hayunanto Medical Center masih dilakukan secara manual dalam pencatatan pasien yang ingin konsultasi. Sehingga masih memiliki berbagai kekurangan dan kendala yang dihadapi. Kendala yang dihadapi yaitu sulitnya mendata banyak pasien yang konsultasi setiap hari, proses pendataan yang banyak mengakibatkan pegawai harus kerja extra ketika pasien yang ingin konsultasi banyak, peramalan diagnosis yang kurang akurat karena dikerjakan secara manual belum adanya sistem pendukung untuk mempermudah mendiagnosis suatu pasien. Kondisi Pasien yang tidak menentu seiring berubah- ubahnya gejala pasien, mengakibatkan kesulitan untuk menentukan penyakit pasien.

Dari permasalahan tersebut, digunakanlah metode Naive Bayes untuk prediksi hasil diagnosis pada Hayunanto Medical Center dengan masa periode setiap bulan dari Bulan Januari 2019 - juli 2019. Menggunakan sistem peramalan berbasis Web PHP Native agar lebih tepat dan akurat dalam melakukan perhitungan.Salah satu metode yang dapat digunakan adalah Naive Bayes yaitu kegiatan memperkirakan atau memprediksikan apa yang akan terjadi pada pasien yang konsultasi dengan kurun waktu tertentu..

Penelitian ini menggunakan Metode Naïve Bayes, dimana penelitian ini menetukan apakah seseorang terkena penyakit skizofrenia atau tidak dengan menghitung kemungkinan dari penyakit dan gejala-gejala yang timbul berdasarkan nilai yang diberikan oleh pakar. Dengan penerapan metode Naive Bayes diharapkan dapat mengetahui gejala penyakit skizofrenia dengan hasil yang akurat.

Melihat betapa pentingnya sistem pakar sebagai program aplikasi yang ditujukan untuk penyedia informasi dan sarana untuk memecahkan masalah di bidang-bidang spesialisasi tertentu, khususnya dalam mempermudah dan mempercepat proses mendiagnosa penyakit skizofrenia maka penulis mencoba untuk meneliti, merancang dan membangun dan kemudian 
menuangkannya dalam bentuk skripsi yang berjudul "Perbandingan Metode Naïve Bayes Dan Bayesian Untuk Diagnosis Penyakit Skizofrenia Berbasis Web".

\subsection{Rumusan Masalah}

Berdasarkan permasalahan yang telah dipaparkan dilatar belakang, maka masalah dapat dirumuskan sebagai berikut :

1. Bagaimana merancang dan membangun suatu sistem pakar untuk diagnosa penyakit Skizofrenia menggunakan metode Naive Bayes berbasis Web ?

2. Bagaimana mengembangkan sistem prediksi diagnosa penyakit Skizofrenia dengan menggunakan metode Nä̈ve Bayes dan Network Bayes pada Hayunanto Medical Center?

\subsection{Batasan Masalah}

Untuk lebih memfokuskan pada permasalahan yang akan diteliti, maka penelitian ini dibatasi sebagai berikut :

1. Website ini dibangun dengan menggunakan PHP sebagai Server Side Programming dan MySQL sebagai database servernya.

2. Aplikasi ini hanya mendiagnosis tentang penyakit Skizofrenia.

3. Data penyakit diambil dari konsultasi dengan pakar dr. Iwan Sys. SpKJ di "Hayunanto Medical Center"

4. Data Aset yang digunakan dalam penelitian ini adalah Data Penyakit, Data Gejala dan Data Aturan.

\subsection{Tujuan}

Adapun tujuan yang ingin dicapai dalam penelitian ini adalah

1. Tujuan dari dibuatnya penelitian ini untuk membangun suatu sistem pakar untuk diagnosa penyakit skizofrenia menggunakan metode Naive Bayes.

2. Membuat sistem pakar untuk penyakit skizofrenia untuk membantu dokter menerapkan kepakarannya dan memberikan informasi tentang penyakit skizofrenia berdasarkan analisis gejala dan penyakit.

3. Menerapkan metode Naive Bayes pada sistem pakar untuk menentukan prediksi kepastian penyakit.

\section{TINJAUAN PUSTAKA}

\subsection{Penelitian Terkait}

Menurut penelitian Rima Diah Wardhani (2017), Schizofrenia merupakan salah satu gangguan jiwa yang mna penderita mengalami gangguan parah terhadap mental, yng ditandai dengan gangguan pikiran, bahasa, persepsi, dan kesdaran diri. Ini sering mencangkup gangguan psikotik, seperti mendengar suara atau biasa disebut delusi. Pada umumnya scizofrenia dimulai pada akhir masa rmaja atau dewasa.

Jenis gangguan jiwa berat scizorenia ini termasuk gangguan jiwa berat. Sehingga siapapun dapat terjangkit penyakit ini, terutama bagi anak yang masih butuh perhatian dari orang disekitar, apabila seorang anak sampai kurang rasa aman atau perhatian oleh lingkungan dan orang sekitar akan sadang berdapak pada psikologis anak tersebut.

Jika penderita scizofrenia ini tidak segara ditangani dan diperhatikan scara cepat dan akan sangat berdampak buruk misalnya, dikucilkan dari lingkungnnya, penderita dpat melakukan tindakan bunuh diri atau tindakan pembunuhan dan hal yang tidak dapat di perkirakan.

Sampain sekarang di negata kita, pengobatan, fasilitas, dan layanan kesehata dibidang kejiwaan masih kurang memadai. Sehingga masyarakat memperlakukan penderita penyakit Skizofrenia sangan tidak layak ,bahkan sampai pemasukan dilakukan kepada penderita penyakit ini.

Schizofrenia dapat dideteksi secara dini dengan mengetahui gejala yang ada pada pasien. Dokter pakar akan mendata gejala-gejala yang dialami oleh pasien, dan dari daftar gejala tersebut dapat ditentukan proses diagnosis. Penyakit Skizofrenia pada umumnya terdiri dari beberapa jenis penyakit, teapi dibedakan dengan berbagai jenis gejala sehingga penyakit A tidak selalu sama dengan penyakit $\mathrm{B}$. Hal ketidakpastian tersebut menyebabkan dokter umum, puskesmas, mantri tidak bisa mendiagnosa penyakit seperti ini.

Dengan adanya masalah tersebut maka penulis membuat sebuah aplikasi "Sistem Pakar Diagnosis Penyakit Schizophrenia Menggunakan Metode Naive Bayes". Naive Bayesdan Bayesian Network merupakan salahsatu metode pembelajaran mesin yang memanfaatkan perhitungan probabilitas dan statistika yang memprediksi kemungkinan di masa depan berdasarkan pengalaman dimasa lalu.

\subsection{Sistem Pakar}

Sistem pakar merupakan cabang dari ArtificialIntelligence atau biasa di sebut (AI) yang membuat ekstensi khusus untuk spesialisasipengetahuan guna memecahkan suatu permasalahan yang di alami Human Expert atau para ahli. Human Expert merupakan seseorang yang ahli dalam suatu bidang ilmu pengetahuan tertentu, ini berarti bahwa expert memiliki suatu pengetahuan khusus yang dimiliki oleh orang lain dan dapat memecahkan suatu permasalahan yang tidak dapat dipecahkan oleh orang lain dengan cara efisien. Pengetahuan ini berasal dari orang atau pengetahuan yang berasal dari buku-buku referensi, surat kabar atau karya ilmiah orang lain. Pengetahuan manusia ke dalam komputer, agar dapat menyelesaikan masalah seperti yang biasa dilakukan oleh para ahli. 
Dengan kata lain sistem pkar adlah sistem yang didesain dan di implementasikan dengan bantuan bahasa pemrograman tertentu untuk dapat menyelesaikan masalah seperti yang dilakukan oleh para pakar dalam hal ini adalah dokter.

\subsection{Struktur Sistem Pakar}

Sistem pakar disusun oleh dua bagian utama, yaitu lingkungan pengembangan dan lingkungan konsultasi .Lingkungan pengembangan sistem pakar digunakan untuk memasukkan pengetahuan pakar ke dalam sistem pakar, sedangkan lingkungan konsultasi digunakan pengguna yang bukan pakar guna memperoleh pengetahuan pakar.

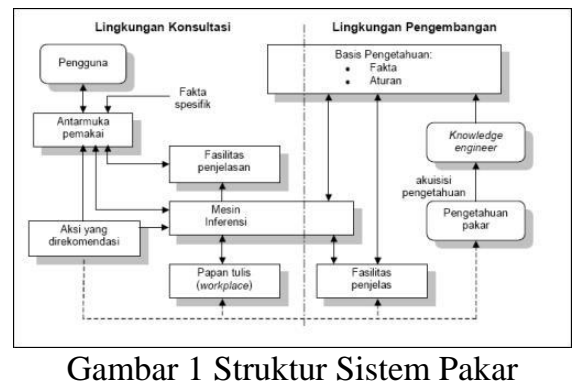

\subsection{Metode Naive Bayes}

Nä̈ve Bayes merupakan metode klasifikasi menggunakan metode kemungkinan yang digunakan untuk memprediksi masa yang akan datang berdasarkan pengalaman di masa lalu sehingga dikenal sebagai Teorema Bayes. Ciri utama dari Nä̈ve Bayes Classifier. Maka Teorema Bayes dirumuskan sebagai berikut :

$$
\mathrm{P}(\mathrm{H} \mid \mathrm{X})=\frac{\mathrm{P}(\mathrm{X} \mid \mathrm{H})}{\mathrm{P}(\mathrm{X})} \cdot \mathrm{P}(\mathrm{H})
$$

Keterangan :

$\mathbf{X}$ : Data dengan class yang belum diketahui

H : Hipotesis data merupakan suatu class spesifik

$\mathbf{P}(\mathbf{H} \mid \mathbf{X})$ : Perkiraan hasil dari $\mathrm{H}$ berdasar kondisi $\mathrm{X}$

$\mathbf{P}(\mathbf{H})$ : Perkiraan Hasil dari $\mathrm{H}$

$\mathbf{P}(\mathbf{X} \mid \mathbf{H})$ : Kemungkinan nilai $\mathrm{X}$ berdasarkan kondisi pada perkiraan $\mathrm{H}$

$\mathbf{P}(\mathbf{X})$ : Kemungkinan $\mathrm{X}$

Theorema Bayes sering pula dikembangkan mengingat berlakunya hokum probabilitas total, menjadi seperti berikut :

Keterangan :

$$
\mathrm{P}(\mathrm{H} \mid \mathrm{X})=\frac{\mathrm{P}(\mathrm{X} \mid \mathrm{H})}{\sum_{i=1}^{n} \mathrm{P}\left(\mathrm{H}_{i} \mid \mathrm{X}\right)} \cdot \mathrm{P}(\mathrm{H})
$$

I : $1,2,3, \ldots, \mathrm{n}$ jumlah data hipotesis (prior probabilitas)

Dimana $: \mathrm{h}_{1}, u \mathrm{~h}_{2}, u \mathrm{~h}_{3}, \ldots, \mathrm{u} \mathrm{h}=\mathrm{s}$

S : Probabilitas total $h$

\subsection{Metode Bayesian Network}

Bayesian Network $(B N)$ adalah model grafis kemungkinan yang merepresentasikan serangkaian variabel dan keterkaitan antar variabel tersebut. Di dalam Bayesian Network dapat menunjukan probabilitas hubungan antara kejadian-kejadian yang saling berhubungan maupun tidak berhubungan.

Struktur graf pada Bayesian Network disebut dengan directed acyclic graph (DAG), yaitu bentuk berarah tanpa siklus berarah. $D A G$ terdiri dari variable-variable yang merepresentasikan adanya hubungan ketergantungan langsung (hubungan sebab akibat antar variabel yang dihubungkan). Tidak adanya vairabel menandakan adanya hubungan kebebasan kondisional di antara variabel.
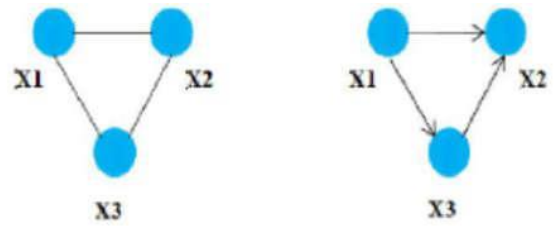

Gambar 2 Directed Acyclic Graph (DAG)

\section{METODE PENELITIAN}

\subsection{Desain sistem}

Dalam system prediksi diagnosa yang dikembangkan dalam penelitian ini menggunakan metode Nä̈ve Bayes yang diaplikasikan pada perhitungan nilai prediksi. Desain sistem di tunjukan pada Gambar 3

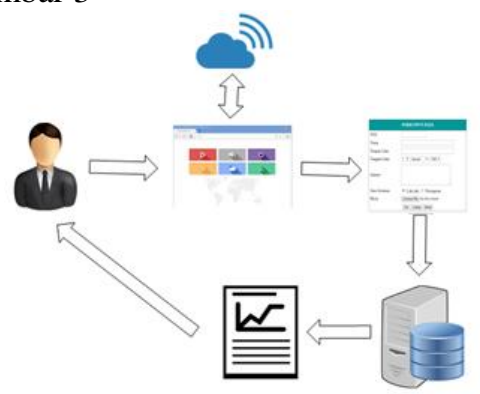

Gambar 3 Desain sistem

Pada gambar 1 Admin / Pemilik membuka browser dan membuka sistem Pakar Diagnosa Penyakit Skizofrenia, lalu admin mengisi data pasien dan gejala yang sering timbul pada pasien yang akan dilakukan perhitungan probabilitas lalu akan ditampilkan hasil prediksi.

\subsection{Struktur Menu}

Struktur menu merupakan struktur yang menampilkan menu apa saja yang terdapat didalam aplikasi. Struktur menu yang akan dirancang di dalam aplikasi ini adalah sebagai berikut : 


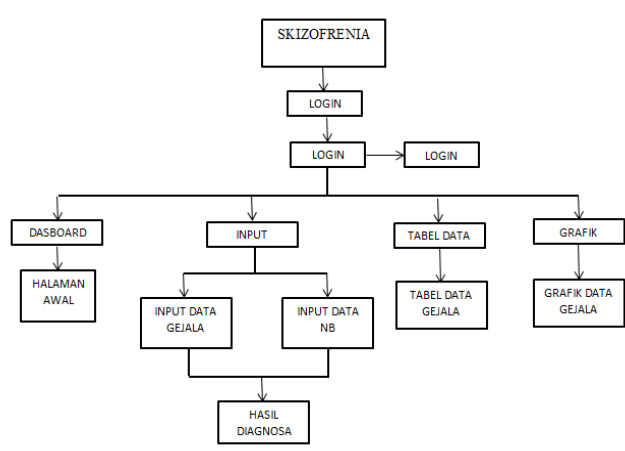

Gambar 4 Sturktur menu

Penjelasan lebih rinci dari gambar 4 adalah sebagai berikut

1. Buka aplikasi Perbandingan Metode Naive Bayes dan Bayesian Network untuk diagnosa penyakit Skizofrenia Berbasis WEB.

2. Pada saat pertama kali dibuka akan diarahkan ke halaman Dasboard.

3. Pada sisi user terdapat menu seperti :
a. Halaman Dasboard
b. Halaman Input
c. Halaman Tabel Data
d. Grafik

\subsection{Flowchart Sistem}

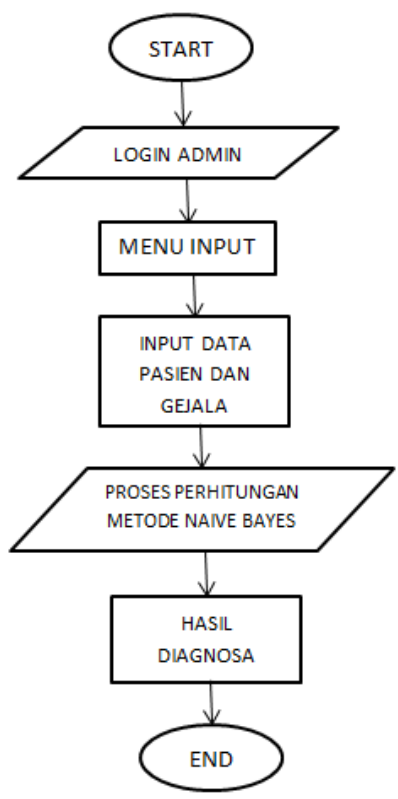

Gambar 5 Flowchart Sistem

Pada gambar 5 Ditunjukan alur kerja sistem pertama admin login kemudian memilih menu input , pilih input data gejala dan menginputkan data pasien beserta gejala yang timbul yang di inputkan kemudian memanggil data lama, dan data baru lalu di bandingkan untuk mencari nilai prediksi dengan menggunakam metode Naïve Bayes jika data berhasil maka keluar hasil perhitungan prediksi jika tidak kembali ke input data.

\section{Hasil Dan Pembahasan}

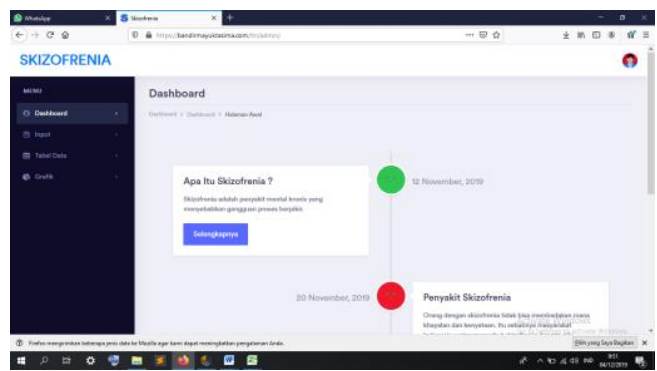

Gambar 6 tampilan home untuk user

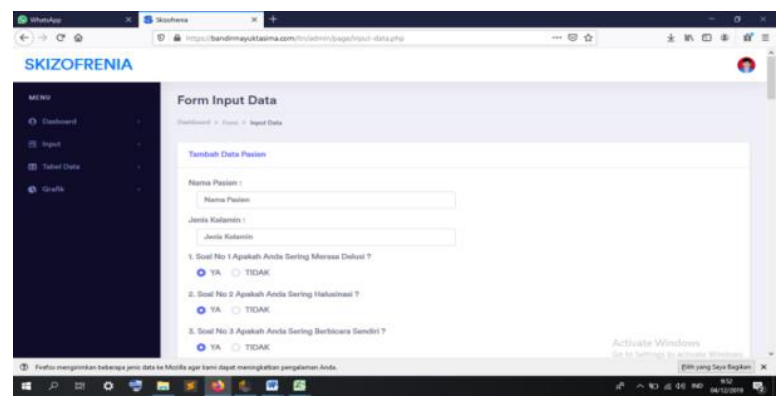

Gambar 7 tampilan menu input data gejala

\subsection{Pengujian Fungsional Sistem}

Pengujian fungsional sistem dari data latih yang dilakukan dengan merubah jumlh dan variasi dari data latih. Data tersebut berjumlah 25. Pada pengujian ini akan dilakukan 2 kali pengujiandan setiap pengujian menggunakan data latih berjumlah 20, 25 dan Selain itu, pengujian data latih juga dilakukan menggunakan jumlah setiap kelas sama. Pada tabel-tabel berikut dapat dilihat hasil dari pengujian varasi data latih.

\section{Tabel 1}

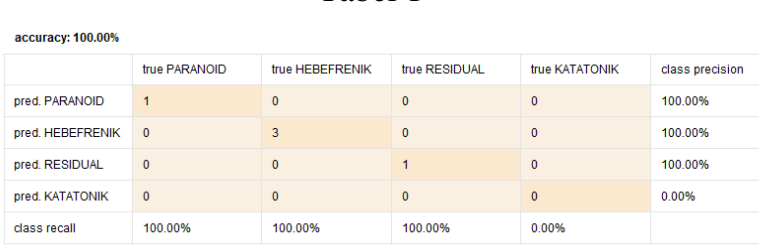

Pada tabel 2 di atas Cell yang berwarna cream pekat adalah hasil sistem sesuai dengan pakar , akurasi yang di dapat dengan 20 data latin ini sebesar $100 \%$ dengan perhitungan.

Kemudian hasil pengujian 25 data dapat dilihat pada tabel 2 
Tabel 2. Pengujian dengan 25 Data Latin

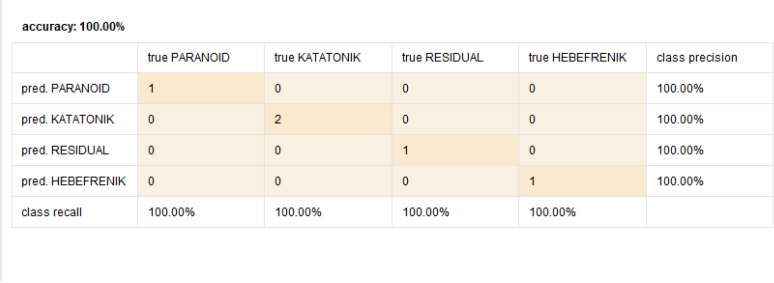

Pada tabel 2 di atas Cell yang berwarna cream pekat adalah hasil sistem sesuai dengan pakar , akurasi yang di dapat dengan 25 data latin ini sama yaitu sebesar 100\% dengan perhitungan.

\subsection{Analisa Pengujian Variasi Data latin}

Berdasar hasil pengujian pada tabel 1 dan 2 dihasilkan nilai akurasi yang sama, dengan nilai akurasi yaitu 1 atau $100 \%$. Nilai akurasi yang sama tersebut membuktikan bahwa variasi dari data latih tidak mempengaruhi akurasi dari sistem.

Dengan nilai akurasi $100 \%$ tersebut, sistem dikatakan baik atau bagus dalam mendiagnosis dikarenakan dalam bidang kedokteran maupun psikologi-pun nilai akurasi tersebut juga cukup baik. Selain itu, penanganan dari data uji yang salah tersebut juga tidak jauh berbeda.

\section{KESIMPULAN}

\subsection{Kesimpulan}

Berdasarkan implmentasi dan pengujian yang dilakukan dapat ditarik kesimpulan bahwa :

1. Dari hasil pengujian fungsional Metode Naive Bayes yang dilakukan pada 25 data testing, Metode tersebut dapat menghasilkan akurasi tinggi dalam mendiagnosa penyakit Sizofrenia.

2. Dari hasil pengujian perbandingan Naive Bayes dan Network Bayes, di temukan perbedaan yang menonjol, dikarenakan perbedaan terdapat pada gejala yang di gunakan dalam perhitungan sangat berbeda, sehingga menghasilkan diagnosa yang kurang sempurna pada perhitungan metode Network Bayes.

\subsection{Saran}

1. Dari beberapa kesimpulan yang telah diambil, maka didapat saran-saran yang akan sangat membantu untuk pengembangan perangkat lunak ini selanjutnya adalah sebagai berikut :

2. Disarankan untuk mempelajari dulu data yang akan digunakan untuk metode Bayesian Network
, agar tidak mendaptkan hasil akhir yang kurang maksimal.

3. Pada penelitian tentang penerapan metode naïve bayes untuk memprediksi diagnosa penyakit di Hayunanto Medical Center dapat dikembangkan dengan metode lain yaitu dengan metode $L S M$, DECISION TREE, Fuzzy Time Series dan lain sebagainya.

\section{DAFTAR PUSTAKA}

[1] Bustami, 2013. Klasifikasi Data Nasabah Asuransi Dengan Menggunakan Metode Naïve Bayes Classifier. Universitas Malikussaleh, Kabupaten Aceh Utara.

[2] Alfa Saleh, 2015. Prediksi Besarnya Penggunaan Listrik Rumah Tangga Dengan Metode Nä̈ve Bayes Classifier. Universitas Potensi Utama, Medan.

[3] Alfa Saleh, 2015. Prediksi Kelulusan Mahasiswa Dalam Mengikuti English Proficiency Test Dengan Menggunakan Metode Naïve Bayes Classifier.Universitas Potensi Utama, Medan.

[4] Harwati, Hanna Miratama, 2016. Prediksi Prestasi Mahasiswa Dengan Jalur Siswa Berprestasi Menggunakan Metode Nä̈ve Bayes Classifier. Universitas Islam Indonesia, Yogyakarta.

[5] Wardhani , Rima Diah 2017. Sistem Pakar Diagnosis Penyakit Schizophrenia Menggunakan Metode Bayesian Network

[6] Fathur Rahman, Muhammad Iqbal Firdaus, 2016. Prediksi Hasil Belajar Siswa Sekolah Menengah Pertama Dengan Menggunakan Metode Naüve Bayes Classifier. Universitas Islam Kalimantan, Banjarmasin.

[7] Sikki, M.I., 2012. Pengenalan wajah menggunakan k-nearest neighbour dengan praproses transformasi wavelet. Jurnal LPPM: PARADIGMA, 10(02).

[8] Hasniati, Arianti, Philip, 2018. Penerapan Metode Bayesian Network Model Untuk Menghitung Probabilitas Penyakit Sesak Nafas Bayi. Makassar.

[9] ORISA, Mira; SANTOSO, Purnomo Budi; SETYAWATI, Onny. Sistem Pakar Diagnosis Penyakit Kambing Berbasis Web Menggunakan Metode Certainty Factor. Jurnal EECCIS, 2014, 8.2: $151-156$ 